\title{
Retinal dysplasia in the crab-eating fox (Cerdocyon thous)
}

\author{
Displasia Retiniana em cachorro-do-mato (Cerdocyon thous)
}

\author{
Roberta RENZO ${ }^{1}$; Alexandre Augusto Franchi de BARROS SOBRINHO ${ }^{1}$; Denise Granato CHUNG ${ }^{1}$; \\ Aline Eyko KAWANAMI²; Juliana Paula de OLIVEIRA ${ }^{2}$; Karin WERTHER ${ }^{2}$; José Luiz LAUS ${ }^{1}$
}

\author{
${ }^{1}$ Universidade Estadual Paulista "Júlio de Mesquita Filho", Faculdade de Ciências Agrárias e Veterinárias, Departamento de Clínica \\ e Cirurgia Veterinária, Jaboticabal - SP, Brazil \\ ${ }^{2}$ Universidade Estadual Paulista "Júlio de Mesquita Filho", Faculdade de Ciências Agrárias e Veterinárias, Departamento de \\ Patologia Veterinária, Jaboticabal - SP, Brazil
}

\begin{abstract}
Previously described in humans and domestic animals, retinal dysplasia has three clinical forms: focal/multifocal, geographic and total. A young orphan crab-eating fox (Cerdocyon thous) from wildlife, male, approximately 45 days old referred to the Wildlife Medicine and Ophthalmology Services of the "Governador Laudo Natel" Veterinary Hospital of the Universidade Estadual Paulista, Jaboticabal Campus, SP, Brazil, where it received primary outpatient care. The patient was in good general health condition, without hematological, biochemistry or serological alterations and no signs of visual impairment. Indirect binocular ophthalmoscopy showed retinal changes in the left eye, distributed over the tapetal area in the form of grayish folds and rosettes. In the affected areas, tapetal reflectivity was reduced. No other ophthalmic abnormalities were observed. This is the first report of retinal dysplasia in the crab-eating fox (Cerdocyon thous) from wildlife.
\end{abstract}

Keywords: Retinal dysplasia. Eyes. Retina.

\section{Resumo}

Descrita no homem e em animais domésticos, a displasia de retina, se apresenta nas formas focal/multifocal, geográfica e completa. Um espécime de cachorro-do-mato (Cerdocyon thous) de vida livre, macho, com 45 dias de vida foi capturado e encaminhado aos Serviços de Medicina de Animais Selvagens e de Oftalmologia do Hospital Veterinário "Governador Laudo Natel” da Universidade Estadual Paulista - Unesp, Câmpus Jaboticabal-SP, Brasil, onde recebeu atendimento primário ambulatorial. O paciente apresentava-se em bom estado geral, sem alterações hematológicas e sorológicas, e não havia sinais de déficit visual. A oftalmoscopia binocular indireta mostrou alterações retinianas no olho esquerdo, distribuídas na área tapetal na forma de pregas e de rosetas de coloração acinzentada. Nas áreas acometidas, a reflectividade tapetal estava reduzida. Não foram observadas outras alterações oftálmicas. Trata-se do primeiro relato de literatura sobre displasia retiniana em cachorrodo-mato (Cerdocyon thous).

Palavras-chave: Displasia retiniana. Olhos. Retina.

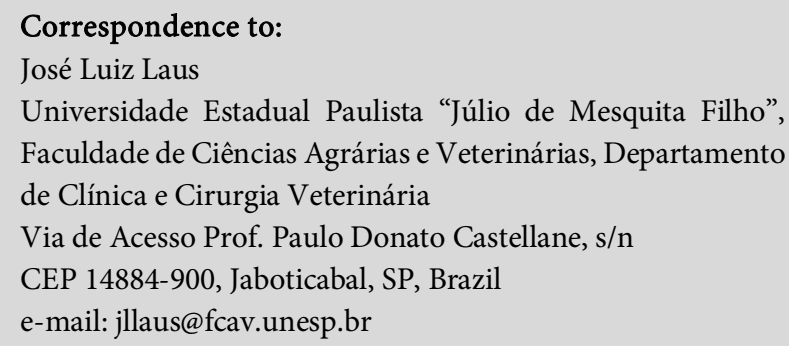

Received: 22/12/2015

Approved: 01/06/2016

The crab-eating fox, Cerdocyon thous, is a medium-sized wild canid, that lives in Brazil in forest areas, in cerrados and in meadows, except in the low areas of the Amazon basin. The species also occurs in Colombia, Paraguay and Uruguay
(BERTA, 1982; BEISIEGEL et al., 2013). Few is known regarding the ophthalmic conditions of this animal.

Retinal dysplasia has been described in all domestic species, though dogs are the most frequently affected (NARFSTRÖM; PETERSEN-JONES, 2013). Among nondomestic species, the condition has been described in otters (WILLIAMS et al., 2004) and in one hawk specimen (DUKES; FOX, 1983). To our knowledge, there are no reports in wild carnivore species.

The hereditary form of the disease has been reported in dogs (NARFSTRÖM; PETERSEN-JONES, 2013). The nonhereditary form presents during the occurrence of infectious disorders, vitamin A deficiency, X-ray irradiation, in poisoning and as a result of intrauterine trauma (NARFSTRÖM; PETERSEN-JONES, 2013). Differentiation 
between a hereditary and nonhereditary cause is not possible by ophthalmic evaluation alone; it requires genetic studies (LONG; CRISPIN, 1999).

Retinal dysplasia can be unilateral or bilateral and is morphologically classified into three forms: focal/multifocal, geographic and total, with retinal detachment. The focal/multifocal form is characterized by folds and rosettes, which present as areas of reduced reflectivity located in the tapetal region. The vision is generally not affected and the lesions may disappear as the patient ages (NARFSTRÖM; PETERSEN-JONES, 2013).

An orphan, male crab-eating fox (Cerdocyon thous), approximately 45 days old from the wildlife was referred to the Wildlife Medicine Service of the "Governador Laudo Natel" Veterinary Hospital of the Faculdade de Ciências Agrárias e Veterinárias-FCAV (Faculty of Agricultural and Veterinary Sciences) of the Universidade Estadual Paulista UNESP (São Paulo State University), Jaboticabal Campus -
SP, Brazil, for evaluation and care. The patient was in good general health, showed no hematological changes and there was no history or signs of visual impairment. The young animal was kept in captivity and adapted to the daily care and management, making possible the realization of eye exams only under physical restraint. A routine ophthalmic evaluation, as part of a health checkup was done when the animal was five months old.

Indirect ophthalmoscopy (indirect ophthalmoscope, Eye $\mathrm{Tec}^{\circ}$ ) showed retinal changes in the left eye, distributed over the tapetal area in the form of grayish folds and rosettes, consistent with multifocal retinal dysplasia. In the affected areas, tapetal reflectivity was reduced (Figure 1). In the case reported herein, changes indicative of the focal/multifocal form were present and no other ophthalmic changes were observed. The fox's vision was apparently normal. Serology by Indirect Immunofluorescent Assay test (IFAT) for Toxoplasma gondii and Neospora caninum were negative.

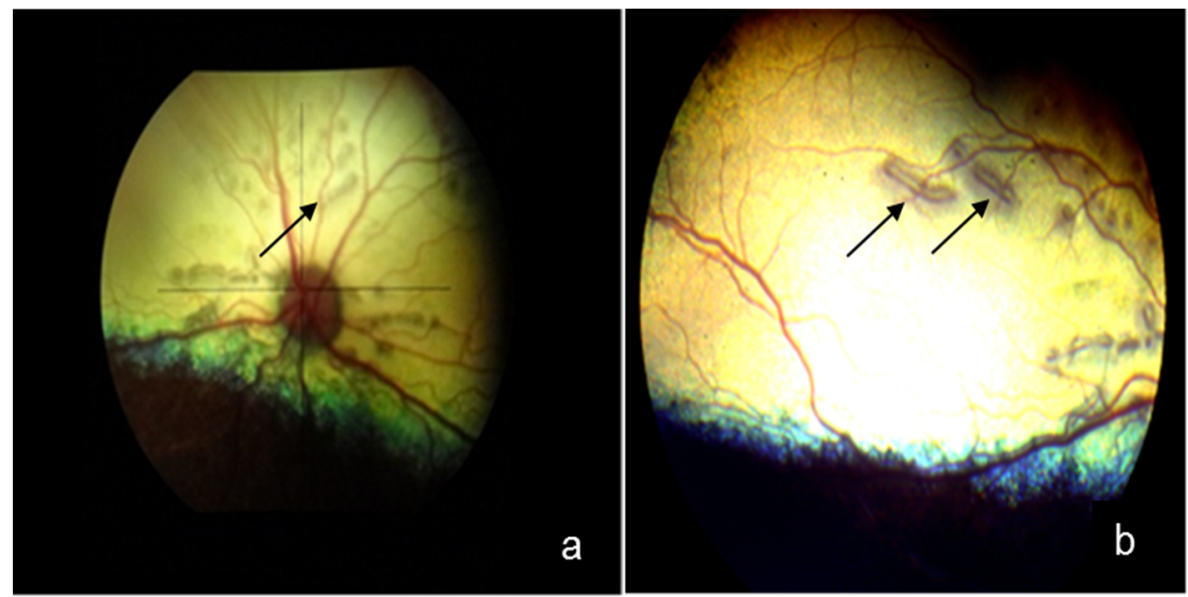

Figure1 - Photographic images of the fundus of the left eye of young crab-eating fox (Cerdocyon thous). Note the presence of linear lesions (folds) distributed multifocally in the tapetal region (arrows) (a), grayish in color and presenting hyporeflectivity (arrows) (b)

Retinal dysplasia can occur due to hereditary and nonhereditary (congenital) causes. The former has been described in dogs, and in the American Cocker Spaniel and English Springer Spaniel breeds, it is the result of autosomal recessive genetic inheritance. In the Labrador Retriever, inheritance is believed to be dominant with incomplete penetrance (NARFSTRÖM; PETERSEN-JONES, 2013). To our knowledge, no other description of retinal dysplasia in a specimen of the crab-eating fox exists in the literature, and in this case, the unknown genealogy of the patient makes it impossible to determine the underlining causes of the disease.
Besides the hereditary form, retinal dysplasia can occur congenitally due to vitamin A deficiency, through poisoning, infectious disorders, following X-ray irradiation and due to intrauterine trauma (NARFSTRÖM; PETERSEN-JONES, 2013).

A study in England reported the occurrence of retinal dysplasia in wild otters (Lutra lutra). The affected animals presented low levels of vitamin A in liver samples, and the authors determined that this decrease in vitamin A was directly related to high concentrations of pesticides (hydrocarbons) (WILLIAMS et al., 2004). In addition to potentially inducing retinal dysplasia, during fetal 
development, vitamin A deficiency promotes other disorders, including hydrocephalus, joint alterations and necrosis of the optic nerve, as described in calves (VAN DER LUGT; PROZESKY, 1989).

The cause of the ophthalmic findings described in this paper has not been identified. The specimen was found in close proximity to an urban area. This could have facilitated contact with infectious agents that promote systemic and ophthalmic changes; however, clinical evaluations and laboratory tests (hematology, biochemistry and serology) showed no changes that indicated the occurrence of diseases of this nature. It is worth emphasizing that the individual was maintained at the veterinary hospital for nine months, which should have been enough for the identification of any changes caused by systemic diseases.

There are reports describing crab-eating foxes infected with distemper virus (MEGID et al., 2009) and rabies

\section{References}

BEISIEGEL, B. M.; LEMOS, F. G.; AZEVEDO, F. C.; QUEIROLO, D.; PINTO, R. S. Avaliação do risco de extinção do cachorro do mato Cerdocyon thous (Linnaeus, 1766) no Brasil. Biodiversidade Brasileira, v. 3, n. 1, p. 138145, 2013.

BERTA, A. Cerdocyon thous. Mammalian Species, v. 186, p. 1-4, 1982. doi: $10.2307 / 3503974$.

CARNIELI JUNIOR, P.; CASTILHO, J. G.; FAHL, W. O.; VÉRAS, N. M. C.; CARRIERI, M. L.; KOTAIT, I. Molecular characterization of Rabies Virus isolates from dogs and crab-eating foxes in Northeastern Brazil. Virus Research, v. 141, n. 1, p. 81-89, 2009. doi: 10.1016/j.virusres.2008.12.015.

DUKES, T. W.; FOX, G. A. Blindness associated with retinal dysplasia in a prairie falcon, Falco mexicanus. Journal of Wildlife Diseases, v. 19, n. 1, p. 66-69, 1983. doi: 10.7589/0090-3558-19.1.66.

LONG, S. E.; CRISPIN, S. M. Inheritance of multifocal retinal dysplasia in the golden retriever in the UK. The
(CARNIELI JUNIOR et al., 2009); however, there are no records of infections in individuals of this species due to adenovirus or canine herpesvirus, reported as possible triggers of retinal changes in dogs.

In conclusion, this paper is the first report of retinal dysplasia in a wild canid and, as such, reinforces the growing need for studies on ophthalmic parameters in species of wildlife, aimed at extending current diagnostic and therapeutic procedures.

\section{Acknowledgements}

The authors are grateful to the Coordination for the Improvement of Higher Education Personnel (CAPES), the National Council for Scientific and Technological Development (CNPq - 300833/2010-5) and the São Paulo Research Foundation (FAPESP - 2009/51773-4) for their support of our research.

Veterinary Record, v. 145, n. 24, p. 702-704, 1999. doi: 10.1136/vr.145.24.702.

MEGID, J.; SOUZA, V. A. F.; TEIXEIRA, C. R.; CORTEZ, A.; AMORIN, R. L.; HEINEMMAN, M. B.; CAGNINI, D. Q.; RICHTZENHAIN, L. J. Canine distemper virus in a crab-eating fox (Cerdocyon thous) in Brazil: case report and phylogenetic analyses. Journal of Wildlife Disease, v. 45, n. 2, p. 527-530, 2009. doi: 10.7589/0090-3558-45.2.527.

NARFSTRÖM, K.; PETERSEN-JONES, S. Disease of the canine ocular fundus. In: GELATT, K. N. Veterinary ophthalmology. $4^{\text {th }}$ ed. Baltimore: Lippincott Williams \& Wilkins, 2013. p. 1303-1392.

VAN DER LUGT, J. J.; PROZESKY, L. The pathology of blindness in new-born calves caused by hypovitaminosis $\mathrm{A}$. Onderstepoort Journal Veterinary Research, v. 56, n. 2, p. 99-109, 1989. doi: 10.1177/0300985875012005-00606.

WILLIAMS, D. L.; SIMPSON, V. R.; FLINDALL, A. Retinal displasia in wild otters (Lutra lutra). The Veterinary Record, v. 155, n. 2, p. 52-56, 2004. doi: 10.1136/vr.155.2.52. 